\title{
SKRINING KANKER SERVIKS DENGAN PEMERIKSAAN PAP SMEAR PADA PROFESI BIDAN DI RUMAH SAKIT TK II PUTRI HIJAU MEDAN TAHUN 2017
}

\author{
Screening of Cervic Cancer With Pap Smear Examination \\ in Midwife Profession in Putri Hijau Hospital 2017 \\ Syaiful $^{1}$, Frida Lina Tarigan ${ }^{2}$, Fikarwin Zuska ${ }^{2}$ \\ ${ }^{1}$ Mahasiswa Program Studi Magister Ilmu Kesehatan Masyarakat \\ ${ }^{2}$ Staf Pengajar Direktorat Pascasarjana Universitas Sari Mutiara Indonesia \\ Email : syaiful_trovas20@yahoo.com
}

\begin{abstract}
Abstrak
Kanker serviks adalah tumor ganas yang tumbuh di dalam serviks (bagian terendah dari rahim yang menempel pada puncak vagina). Pap smear adalah suatu metode di mana dilakukan pengambilan sel dari mulut rahim kemudian diperiksa di bawah mikroskop. Setiap wanita yang telah berusia 18 tahun, atau wanita yang telah aktif secara seksual selayaknya mulai memeriksakan Pap smear. Pemeriksaan ini sebaiknya dilakukan setiap tahun, walaupun tidak ada gejala kanker. Pemeriksaan dilakukan lebih dari setahun jika sudah mencapai umur 65 tahun atau tiga pemeriksaan berturut-turut sebelumnya menunjukkan hasil normal. Tujuan penelitian merubah perilaku profesi bidan agar mau melakukan skrining kanker serviks dengan pemeriksaan pap smear di Rumah Sakit Tk II Putri Hijau Medan. Desain penelitian ini adalah kualitatif melalui pendekatan fenomenologi. Hasil penelitian diperoleh informan sebanyak 8 orang terdiri dari 1 orang informan laki-laki yaitu seorang dokter obgyn, 7 orang berprofesi sebagai bidan yang terdiri dari informan 2 sering melakukan pemeriksaan pap smear. Informan yang tidak rutin melakukan pemeriksaan pap smear yaitu informan informan 3 sebanyak 3 kali, informan 4 sebanyak 1 kali, informan 5 sebanyak 3 kali, informan 6 sebanyak 2 kali. Sedangkan informan 7 belum pernah melakukan pemeriksaan pap smear, dan informan 8 sebanyak 1 kali. Beberapa alasan yang menjadi perubahan perilaku profesi bidan terhadap pemeriksaan pap smear adalah rasa malu (enggan), rasa takut, belum ada keluhan (kelainan), kesetrilan (alat kesehatan), malas dan biaya. Di sini ditemukan ungkapan dari ke 8 para informan adalah perkataan malu yang lebih dominan. Saran kepada Pimpinan Rumah Sakit Tk II Putri Hijau Medan, disampaikan kepada pimpinan agar mewajibkan kepada seluruh staf berjenis kelamin perempuan yang sudah aktif melakukan hubungan seksual untuk melalukan skrining kanker serviks dengan pemeriksaan pap smear secara rutin sesuai prosedur dan dilakukan di Rumah Sakit Tk II Putri Hijau Medan secara gratis dengan fasilitas jaminan kesehatan yang ada.
\end{abstract}

Kata Kunci : Skrining Kanker Serviks, Pemeriksaan Pap Smear, Profesi Bidan

\begin{abstract}
Cervical cancer is a malignant tumor that grows inside the cervix (the lowest part of the uterus attached to the top of the vagina). A Pap smear is a method in which a cell is taken from the cervix and examined under a microscope. Any woman who is 18 years old, or a woman who has been sexually active should begin a Pap smear. This check should be done every year, although there are no symptoms of cancer. An examination of more than a year if it reaches the age of 65 years or three previous consecutive checks shows normal results. The purpose of the study changed the behavior of the midwife profession in order to perform cervical cancer screening with pap smear examination at Tk II Putri Hijau Hospital Medan. The design of this research is qualitative through phenomenology approach. The result of the research was obtained by the informant as many as 8 people consisting of 1 male informant that is obgyn doctor, 7 person work as midwife consisting of informant 2 often doing pap smear examination. Informants who do not routinely perform pap smear examination of informants 3 informants 3 times, informant 4 as much as 1 times, informant 5 as much as 3 times, informant 6 as much as 2 times. While informant 7 has never done pap smear examination, and informant 8 as much as 1 times. Some of the reasons that changed the behavior of the midwife profession to the Pap smear examination were shyness (fear), fear, no complaints (abnormalities), kesetrilan (medical equipment), lazy and cost. Here is found the expression of the eight informants is a more dominant shame words. Suggestion for the Tk II Putri
\end{abstract}


Hijau Medan, submitted to the leader to oblige all female sex workers who have been actively engaged in sexual intercourse to perform cervical cancer screening by Pap smear examination routinely according to procedure and done at Tk II Putri Hijau Hospital Medan for free with existing health insurance facilities.

Keyword: Cervical cancer screening, Pap smear Examination, Midwife Profession.

\section{PENDAHULUAN}

Kanker serviks merupakan keganasan ginekologi yang sering terjadi dan masih menjadi masalah kesehatan yang utama pada wanita khususnya di negara berkembang. Berdasarkan data Globocan 2012, kanker serviks merupakan keganasan terbanyak keempat pada wanita di dunia setelah kanker payudara, kolon, dan paru, dengan insidensi sebanyak 528.000 kasus dan angka kematian mencapai 266.000 kasus. Menurut data dari World Health Organization (WHO), lebih dari 270.000 kasus wanita meninggal dunia karena kanker serviks dan lebih dari $85 \%$ kematian ini terjadi pada negara berkembang.

Jumlah penderita kanker serviks di Indonesia masih sangat tinggi, menurut (Kemenkes RI 2015) angka penderita kanker serviks sebesar $0.8 \%$. Setiap tahun tidak kurang dari 15.000 kasus kanker serviks terjadi di Indonesia. Itu membuat kanker serviks disebut sebagai penyakit pembunuh wanita nomor 1 di Indonesia. Label itu tidak berlebihan karena tiap hari di Indonesia dari 40 wanita yang terdiagnosa menderita kanker serviks, 20 wanita di antaranya meninggal karena kanker serviks.

Menurut Kompas (2013) bahwa Promosi kesehatan dan deteksi dini menjadi prioritas untuk mencegah dan menangani penyakit. Organisasi Kesehatan Dunia (WHO) mencatat, tiap tahun sekitar 15.000 kasus kanker serviks (leher rahim) ditemukan di Indonesia. Indonesia menjadi negara dengan jumlah kasus kanker serviks tertinggi di dunia. Kanker serviks ditandai dengan tumbuhnya selsel tidak normal pada leher rahim. Diperkirakan 90 persen kanker leher rahim disebabkan human papilloma virus (HPV). HPV menyerang kulit dan membran mukosa pada manusia dan hewan. Menular dan berkembangnya HPV disebabkan, antara lain, hubungan seks pada usia muda (di bawah 18 tahun), perilaku seks berisiko, merokok atau terpapar asap rokok (pada perokok pasif), dan kurang menjaga kebersihan.

Berita Satu, (2014) bahwa Kementerian Kesehatan (Kemkes) mencatat dari sekian banyak kanker yang menyerang penduduk Indonesia, kanker payudara dan kanker leher rahim (serviks) tertingi kasusnya di seluruh Rumah Sakit (RS). Berdasarkan Sistem Informasi RS (SIRS), jumlah pasien rawat jalan maupun rawat inap pada kanker payudara terbanyak yaitu 12.014 orang $(28,7 \%)$ dan kanker serviks 5.349 orang (12,8 \%). Baru disusul kanker leukimia sebanyak 4.342 orang $(10,4 \%$, lymphoma 3.486 orang $(8,3 \%)$ dan kanker paru 3.244 orang $(7,8 \%)$.

Kemenkes RI (2014) mengatakan bahwa menurut Program Jaminan Kesehatan Nasional (JKN) yang dilaksanakan oleh Badan Penyelenggara Jaminan Sosial (BPJS) Kesehatan telah menjamin pemeriksaan deteksi dini kanker leher rahim dan payudara bagi para wanita, khususnya yang sudah terdaftar menjadi peserta. Program JKN yang dijalankan oleh BPJS Kesehatan sudah menjamin pemeriksaan IVA, pap smear, bahkan cryotherapy. Pemeriksaan dilakukan sekali dalam kurun waktu lima tahun. Dari data tersebut, suspek kanker leher rahim sebanyak 840 orang (1,3 5 per 1000 penduduk). Cakupan deteksi dini ini masih perlu ditingkatkan dengan kerja keras, kerja cerdas, dan inovasi dari berbagai elemen masyarakat.

Tempo (2014) mengatakan bahwa peningkatan pasien untuk tes pap smear juga terjadi di RS Bhakti Husada, Kecamatan Glenmore. Direktur RS Bhakti Husada, Zunita Ahmadah, mengatakan, pasien tes pap smear saat ini mencapai 500 orang per bulan. Padahal sebelum program pap smear gratis berlaku, pasien pap smear hanya sekitar 50 orang per bulan. "Padahal pap smear gratis dari JKN baru efektif Juli," kata Zunita. Kepala Badan Penyelenggara Jaminan Sosial (BPJS) Kesehatan Kabupaten Banyuwangi, Adi Soe 
narno, mengatakan, menyediakan alokasi anggaran Rp 2,3 miliar untuk program pap smear gratis. Menurutnya, ada 7 rumah sakit dan 2 klinik mobile yang memiliki layanan pap smear gratis bagi pemegang kartu JKN di Banyuwangi.

Promosi merupakan upaya untuk memberitahukan atau menawarkan produk atau jasa dengan tujuan menarik calon konsumen. Berkaitan dengan hal tersebut klinik obgyn telah memberikan fasilitas tempat dalam pengambilan sampel untuk pemeriksaan pap smear. Namun petugas kesehatan khususnya profesi bidan belum menyadari pentingnya dilakukan skrining kanker serviks dengan pemeriksaan pap smear. Hal ini terlihat bahwa ketika kunjungan di klinik obgyn profesi bidan yang datang untuk melakukan pemeriksaan pap smear masih sedikit. Padahal promosi tentang skrining kanker serviks dengan pemeriksaan pap smear sudah disosialisasikan di lingkungan TNI-AD beserta keluarga dan jajaran Kodam I/BB termasuk di dalamnya tenaga kesehatan (profesi bidan) personil Rumkit Tk II Putri Hijau Medan. Bertempat di aula Rumkit Tk II Putri Hijau Medan dengan menghadirkan pembicara dari Dinas Kesehatan Provinsi Sumatera Utara dan pembicara dari Rumah Sakit Tk II Putri Hijau Medan. Untuk pemeriksaan pap smear di Rumah Sakit Tk II Putri Hijau Medan belum bisa dilaksanakan secara gratis, dikarenakan laboratorium tersebut tidak menyediakan layanan untuk pemeriksaan pap smear. Klinik obgyn hanya menyediakan tempat untuk pengambilan sampel saja, sedangkan untuk pemeriksaan sampel dilakukan sesuai rujukan dokter obgyn yaitu laboratorium Prodia dan laboratorium klinik Thamrin dengan biaya dibebankan kepada pasien. Pada momen tertentu laboratorium Prodia melaksanakan pemeriksaan pap smear diberikan secara gratis, seperti HUT Kodam I/BB bekerja sama dengan BKKBN dan dinas kesehatan Provinsi Sumatera Utara, Hari Kesehatan Nasional. Di Laboratorium Prodia dilakukan secara gratis pada saat memperingati Hari Kemerdekaan Indonesia dengan persyaratan foto copi Kartu BPJS, foto copi kartu keluarga dan foto copi KTP. Namun profesi bidan belum turut serta dalam pemeriksaan pap smear dan belum menyadari pentingnya pap smear.

Dan peneliti tertarik untuk melakukan penelitian tersebut dengan ini mengangkat judul "Skrining Kanker Serviks Dengan Pemeriksaan Pap Smear Pada Profesi Bidan Di Rumah Sakit Tk II Putri Hijau Medan Tahun 2017”

\section{METODOLOGI PENELITIAN}

Desain penelitian ini adalah kualitatif melalui pendekatan fenomenologi. Desain fenomenologis digunakan dalam penelitian kualitatif yang bertujuan ingin memahami atau menggali kenyataan yang dialami atau perilaku tertentu individu atau kelompok individu serta aspek-aspek yang mendasari suatu perasaan, pendapat, kejadian, hubungan, dan lain-lain. Desain ini sering digunakan pada penelitian tentang filosofi suatu perilaku atau kejadian tertentu.

Dengan melakukan pendekatan fenomenologi bertujuan untuk melihat fenomena yang terjadi tentang skrining kanker serviks dengan pemeriksaan pap smear pada profesi bidan di Rumah Sakit Tk II Putri Hijau Medan. Penelitian ini menggali secara dalam (Indepth Interview), mengajukan beberapa pertanyaan kepada petugas kesehatan yang ditemui dan berkompeten di ruang kebidanan untuk menghasilkan jawaban dengan baik dalam peran serta mereka melaksanakan skrining kanker serviks dengan pemeriksaan pap smear. Data yang akan diperoleh sebagai laporan berasal dari observasi, wawancara dan dokumentasi yaitu berupa catatan, rekaman, dan foto.

Informan penelitian diperoleh dari beberapa tenaga kesehatan seperti dokter penanggung jawab obgyn dan beberapa orang bidan yang berkompenten di ruang klinik obgyn dan ruang rawat inap kebidanan. Jumlah Informan untuk pengambilan data dalam wawancara disesuaikan dengan kebutuhan dari peneliti. Dan mereka yang menjawab tentang fenomena yang terjadi pada profesi bidan untuk melakukan skrining kanker serviks dengan pemeriksaan pap smear. 
Sumber informasi yang peneliti peroleh berasal dari dokumen yaitu berupa data rekam medik pasien yang berkunjung di klinik obgyn dari jumlah tenaga kesehatan profesi bidan di Rumah Sakit Tk II Putri Hijau Medan sebanyak 42 orang, yang terdiri dari 35 orang berstatus menikah dan 7 orang belum menikah. Dari 35 orang yang sudah menikah terdapat 15 orang belum pernah melakukan pemeriksaan pap smear, dan 20 orang sudah melakukan pemeriksaan pap smear. Informasi lain adalah beberapa informan yang berasal dari tenaga kesehatan seperti dokter dan profesi bidan. Peneliti juga melakukan pengamatan terhadap data, tenaga kesehatan serta fasilitas yang ada di klinik obgyn.

Informan berasal dari tenaga kesehatan yaitu dokter dan bidan yang bekerja di poli obgyn dan ruang rawat inap kebidanan bisa memberikan informasi di dalam penelitian penulis. Dengan demikian penulis memperoleh informan sebagai berikut :

\section{a. Informan 1}

Seorang dokter dengan inisial $\mathrm{M}$, berjenis kelamin laki-laki usia 28 tahun, merupakan salah satu dokter obgyn di Rumah Sakit Tk II Putri Hijau Medan, dengan pendidikan terakhir S2. Pada penelitian ini, beliau bersedia menjadi informan untuk menjawab permasalahan yang ada pada profesi bidan dalam hal skrining kanker serviks dengan pemeriksaan pap smear.

\section{b. Informan 2}

Seorang bidan berinisial E, usia 49 tahun, merupakan bidan penanggung jawab di klinik obgyn dengan latar belakang pendidikan D-4 Kebidanan dan S2 Psikologi. Beliau juga merupakan salah satu bidan yang sering melakukan pemeriksaan pap smear, sehingga bisa mendorong bidan lainnya untuk mau melakukan skrining kanker serviks dengan pemeriksaan pap smear. Saat ini informan tidak menggunakan alat kontrasepsi, akan tetapi menggunakan metode coitus interuptus.

\section{c. Informan 3}

Bidan yang berinisial J, usia 41 tahun, merupakan bidan pelaksana di klinik obgyn, dengan pendidikan terakhir D-3 Kebidanan. Pasangan informan ini tidak menggunakan alat kontrasepsi, tetapi menggunakan metode kalender. Dari pengalaman informan sudah melakukan skrining kanker serviks sebanyak 6 kali dengan metode pemeriksaan Pap smear.

\section{d. Informan 4}

Bidan N, usia 49 tahun, merupakan bidan pelaksana di ruang kebidanan, dengan pendidikan terakhir D-3 Kebidanan. Beliau merupakan bidan senior dan memiliki klinik praktek mandiri di kota Medan, dengan demikian beliau mempunyai banyak pengalaman melihat kegiatan skrining kanker serviks dengan pemeriksaan pap smear berlangsung..Alat kontrasepsi yang digunakan pada keluarga tidak ada (metode kalender) dan informan baru satu kali melaksanakan skrining kanker serviks dengan metode pemeriksaan Pap smear.

\section{e. Informan 5}

Bidan D berusia 40 tahun yang merupakan bidan pelaksana di ruang kebidanan, dengan pendidikan terakhir D-3 Kebidanan. Sampai saat ini informan sudah melakukan skrining kanker serviks dengan pemeriksaan Pap smear sebanyak 3 kali.

\section{f. Informan 6}

Bidan M, usia 39 tahun, merupakan bidan pelaksana di ruang kebidanan, dengan pendidikan terakhir D-3 Kebidanan. Beliau memiliki pengalaman bertugas di tempat lain dan mau mengungkapkan pengalaman selama mengikuti pap smear. Informan sudah melakukan skrining kanker serviks sebanyak 2 kali dengan melakukan metode pemeriksaan Pap smear.

\section{g. Informan 7}

Bidan $\mathrm{T}$ berusia 32 tahun yang merupakan bidan pelaksana di ruang kebidanan, dengan pendidikan terakhir D-3 Kebidanan. Informan belum pernah melakukan skrining kanker serviks.

\section{h. Informan 8}

Bidan E berusia 43 tahun yang merupakan Kepala Ruangan kebidanan, dengan pendidikan terakhir D-4 Kebidanan. Dengan jawabatan sebagai kepala ruangan tersebut peneliti yakin beliau memiliki kemampuan dan tanggungjawab penuh pada ruang kebidanan. Informan baru 1 kali melakukan skrining 
kanker serviks dengan metode pemeriksaan Pap smear dan memiliki alasan tertentu.

Pengumpulan data dilakukan dengan pengumpulan data primer dan sekunder. Data primer dengan melakukan wawancara (In-depth Interview), yaitu keterangan atau informasi yang didapat secara lisan dari informan. Data sekunder diperoleh dari laporan yang berkaitan dari masalah yang diteliti.

Proses pengumpulan data melalui observasi dan wawancara. Dalam menganalisis data yang telah terkumpul dari lapangan adalah metode kualitatif yaitu menginterprestasikan data yang telah diperoleh ke dalam bentuk kalimatkalimat dengan menggunakan beberapa langkah yaitu : pengumpulan data lapangan, reduksi data, penyajian data, dan penarikan kesimpulan.

\section{HASIL PENELITIAN}

Setelah peneliti melakukan wawancara dengan 8 orang informan terdiri dari 1 orang sebagai profesi dokter spesialis obgyn dan 7 orang sebagai profesi bidan bertugas di ruang klinik obgyn dan ruang rawat inap kebidanan. Maka peneliti menemukan beberapa alasan profesi bidan dalam melakukan skrining kanker serviks dengan pemeriksaan pap smear di Rumah Sakit Tk II Putri Hijau Medan, yaitu :

\section{Merasa Malu (Enggan)}

Hasil wawancara peneliti menemukan informan menyatakan rasa malu untuk melakukan pemeriksaan pap smear. Rasa malu (enggan) dibuktikan dengan pernyataanpernyataan yang diperoleh dari masing-masing informan yang didapat. Salah satunya ungkapan malu (enggan) terhadap dokter dan teman kerja di ruang klinik obsgyn. Demikian ungkapan informan tersebut :

"Yang pertama karena malu dengan dokternya laki-laki dan malu dilihat alat kelaminnya, malu ketahuannya penyakitnya, bisanya mereka kalau mau diperiksa pasti karenan ada masalah, untuk diperiksan itu rasa malunya walaupun dengan petugas bidannya teman sendiri juga mereka malu, mereka bilang dokter yang jaga hari ini, tau saya yang jaga mereka gak jadi periksa, iya bu kenapa ibu mau berobat, mereka bilang mau pap smear dokter, saya bilang ke mereka, ya sudah, bu naik ke tempat tidur biar saya periksa, jawab mereka ngaklah dokter saya malu, saya juga gak memaksa, ya kalau ibu gak mau ya gak apaapa, atau sama bidannya bu, ngak dokter lain kali aja”.

(Informan 1)

"Satu alasan yang pernah bilang, dia bilang sungkan untuk buka-buka, dan motivasi tenaga kesehatan masih sedikit, kalau saya sering periksa pap smear, cuma itu tadi teman-teman sama dokter juga malu sama kita juga malu, padahal tetapnya ikhlas kita kerjakan”.

(Informan 2)

"Ngangkang aja malu, malu dengan teman sendiri kalau ngak mau kalipun pap smear, cuma itu tadi yang alat kelamin kita dilihatlihat apa gak risih nantinya, terus kepikiran seperti itu, walaupun kita orang kesehatan tau sih itu salah diperiksa aja ngak mau, padahal kepentingan sendiri harus malu”.

(Informan 3)

"Ada rasa malu, karena dokternya laki-laki, trus buka pakaian, padahal kepengin pap smear, seharusnya orang umum gak malu, kalau orang umum takut ketahuan penyakitnya, kalau orang kesehatan itu ya itulah pertama malu duluan, takut ketahuan penyakitnya, gak usah jauh-jauh awak sendiri kalaupun sama kawan aja malu, ya itu tadilah, dokter itu .... iiih apanya (alat kelamin), itukan disumpah memang kan di mulut, dilapangan gak begitu, ya pernahlah, antara kita aja ada yang cerita kok, namanya juga perempuan pasti malu, dokter aja kalau sama sama dokter juga malu, sedang dokter aja mau diceritain sama pasiennya, jorok kali ibu ini bauk gak tau jaga kebersihan, pasrah, beda dengan nolong persalinan itukan sudah pasrah, kalau sudah stadium berapa baru mau tak mau naiklah, kalau sudah tau kita bidan saat diperiksa dibilang ...ih ibu ini percuma bidan jorok kali, mayoritas malu, mau bidannya mau perawatnya pasti dibilang pertamanya malu, tengok ini contoh kek mana ini bidannya gak tau jaga kebersihan”. 
(Informan 5)

"Malu, malu dibuka, bauk, walaupun ingin pap smear, malu membuka diri, malu menunjukkan alat kemaluan sama orang lain, apalagi di klinik kan saya kenal semua, sedangkan di prodia ajapun kita merasa malu padahal kita gak kenal, apalagi di tempat sendiri, sayakan sudah melahirkan 3 orang anak malu gimana gitu, malu karena bentuknyalah, pokoknya malulah".

(Informan 6)

"Kalau di ginokologi pasti malulah apalagi dengan dokter laki-laki, perasaan gak enak karena kenal, malu dibuka-buka, malu nanti ketahuan penyakitnya, apalagi kita orang kesehatankan, makanya saya baru satu kali rasa malu itu pasti ada".

(Informan 8)

Ungkapan dari 2 informan lainnya, yang menyatakan "malu", terhadap profesi bidan untuk melakukan pemeriksaan pap smear yaitu :

"Kalau saya sih kenapa harus malu, toh juga untuk kesehatan kita, walaupun dibuka-buka, sekalian periksa mana tau ada gejala penyakit lainnya, gimana kalau kita melahirkan toh juga dilihat-lihat .. ya kan”.

\section{(Informan 4)}

"Ngaklah, kok harus malu, terkadang ada keputihan trus pengen periksa pap smear, cuma itu tadi, saya takut dengan cocor bebeknya".

(Informan 7)

\section{Rasa Takut}

Rasa takut merupakan salah satu alasan beberapa informan untuk tidak melakukan pap smear, namun defenisi rasa takut setiap informan memiliki makna yang berbeda. Salah satu makna takut yang diungkapkan adalah takut akan alat yang akan digunakan pada proses pap smear.

Berikut adalah pernyataan rasa takut dari informan pada saat dilakukan wawancara oleh peneliti:
"Takut ketahuan penyakitnya, takut dengan cocor bebek sedikit sakit, itu aja sih, takutb dimarahi dokternya kalau sudah lama kok baru periksa, apalagi kalau tau penyakitnya pasti depresi, kalau dokter bilang sehat pastilah senang, takut kalau ada kanker takut ditinggal suami, takut menghadapi kehidupan di masyarakat, masyarakat akan bertanya, kenapa-kenapa dari mana, trus mikirin pengobatannya lagi”.

(Informan 5)

"Takut ketahuan penyakitnya, pasti sama juga dengan teman-teman rasa ketakutan bila ketahuan penyakitnya apalagi jika ketahuan gejala kanker, tak terbayangkan, harapannya baik-baik aja .. ya kita mana tau namanya juga penyakit entah dari mana datangnya".

(Informan 6)

"Takut, takut dengan alat kesehatannya, pake cocor bebek itukan sedikit sakit ya, trus takut juga kalau ketahuan penyakitnya, padahal kita tau sudah ada gejala keputihan, pengen rasanya diperiksakan ke dokter".

(Informan 7)

Ungkapan dari informan lainnya yaitu yang menyatakan :

"Dari beberapa kunjungan pasien di klinik yang berobat terlihat masyarakat umum yang banyak untuk melakukan pap smear, untuk tenaga kesehatan sendiri, seperti profesi bidan sedikit untuk melakukan pemeriksaan, kalau ditanya mereka takut tidaknya, kemungkinan hanya sedikit yang merasa ketakutan akan penyakitnya, untuk alat kesehatan kita tetap menjaga kesterilan alat, dan ukurannya disesuaikan keadaan pasien”.

(Informan 1)

"Karena saya sering melakukan ini, jadi ngak perlu takut beda dengan teman seprofesi bidan, $Y a$... mungkin mereka takut akan penyakit, bila ketahuan penyakitmya tidak bisa dibayangkan apalagi kalau sudah parah. Kalau hanya ringan-ringan saja pasti mereka minta obat saja”.

(Informan 2) 
"6 kali sudah saya melakukan pap smear, jadi gak perlu takutlah, mau periksanya di klinik obgyn atau ke lab. Luar juga gak perlu takut, awal-awal pertama ajanya itukita takut, pokoknya bisa kita jaga kesehatan kita, amannya itu”.

(Informan 3)

"Rasa takut buat saya jauhlah, gimanapun kita punya pasien pastilah pernah kita sampaikan ke mereka tentang pap smear ini, gak perlu ada rasa takut, ya ... bila ada tanda dan gejala ke arah kanker, dokter akan melakukan pemeriksaan dan memberikan obat bila sudah terlihat tanda dan gejala penyakit”.

(Informan 4)

"Saya rasa kalau kita ingin diperiksa gak perlulah ada rasa takut, yang penting diri kita selalu menjaga kesehatan, menjaga kebersihan sehingga untuk arah ke sana mudahmudahan baik-baik saja, kesalahan hanya tidak secara rutin dilakukan".

(Informan 8)

\section{Belum Ada Keluhan (Kelainan)}

Mencegah lebih baik daripada mengobati, hal ini sering kita dengar. Sebagai profesi bidan pengetahuan tentang kanker serviks sudah lebih baik daripada masyarakat umum, baik terkait dengan pengetahuan tentang tanda dan gejala serta pencegahannya. Latar belakang pengetahuan inilah yang membuat beberapa informan yang berprofesi sebagai bidan menganggap sepele akan pentingnya melakukan pemeriksaan pap smear. Hal ini diungkapkan oleh informan pada saat wawancara. Namun ada pernyataan dari informan yang menyatakan bahwa justru tenaga kesehatan sendiri yang tidak berkeinginan untuk melakukan pemeriksaan pap smear.

"Ada beberapa teman-teman bidan mengapa mereka tidak mau melakukan pap smear salah satunya merasa dirinya selalu menjaga kebersihan, dan untuk melakukan pap smearpun sedikitlah dari mereka yang ingin periksakan dirinya untuk pap smear, bisa dihitung pertahunnya beda dengan masyarakat umum lebih banyak untuk melakukan pap smear".

(Informan 1)

"Sayakan kerjanya di klinik obgyn, setiap ibuibu yang pasang IUD 6 bulan sekali saat kontrol jika ada erosi kita anjurkan untuk pap smear. Idealnya setelah menikah kalau sudah ada indikasi dan kalau ngak ada indikasi 1 tahun sekali, tenaga kesehatan sendiri ada yang melakukan pap smear. Menurut orang dinas kita kerjasama orang dinaskan, jadi sebaiknya IVA dulu, kalau curiga ada misalnya ada gejala, kalau IVA itu hanya melihat aja. Dengan pake asam asetat 5 menit atau berapa menit kemudian ada perubahan dinding serviksnya ada gumpalan warna putih yang terjadi di situ, baru anjurkan untuk pap smear. Motivasi tenaga kesehatan sendiri masih sedikit".

\section{(Informan 2)}

"Karena tidak ada kelainan aja, kalau ada keputihan minum obat aja, mudah-mudahan sembuh, trus jaga-jaga kebersihan celana dalam, jaga makan dan hindari makanan yang membuat timbulnya gejala kanker seperti bakar-bakaran dan olah raga secara teratur dan banyak lagi yang harus kita perhatikan".

(Informan 4)

"Iya, karenakan kita juga tau apa mengapa dilakukan pap smear, gejala-gejala tidak ada keputihan pun tidak ada, suamipun lama selalu di samping, lebih lama di samping daripada di luar, aku yakin aku sehat kok, kalau ada kelainan minum obat tablet diplokan”.

(Informan 8)

Beda dengan ungkapan beberapa informan lainnya yang menyatakan bahwa:

"Seandainyapun tidak ada kelainan atau keluhan terhadap kita dalam hal pap smear, namanya sudah berkeluarga ya, seharusnya tetapnya kita periksakan untuk pap smear, 
jangan menunggu atau sampai ada kelainan pada alat kelamin kita seperti keputihan yang berlebihan, setelah berhubungan dengan suami sering terjadi perdarahan baru kita periksakan, ini namanya terlambat, maunya kita selalu rutin bila ada keluhan”.

(Informan 3)

"Kita tau, apabila ada tanda atau gejala pada alat kelamin kita, pastinya periksakan ke dokter mana tau ada sesuatu yang gak kita harapkan muncul, harapannya ya ... kita lakukan pemeriksaan pap smear, dan bersabar dengan hasil pemeriksaan, mudah-mudahan ya selalu baik".

((nforman 5)

"Kalau ada keluhan pada alat kelamin pasti periksa ke dokter, jangan sampailah kena penyakit lain, mungkin aja keputihan biasa atau terjadi perdarahan tetapi tidak perlu harus pap smear hanya dikasih obat ajalah".

(Informan 6)

"Maunya sih periksa ada tidak ada keluhan, terkadang itu tadi kesibukan kerja, adanya keputihan gak sempatpun berobat, ada aja nanti kerjaan lain".

$$
\text { (Informan 7) }
$$

\section{Kesterilan (Alat Kesehatan)}

Alat kesehatan di klinik Obgyn diperoleh dari Rumah Sakit dan rekanan instansi pemerintah maupun swasta. Informasi yang diperoleh dari informan mengatakan tenaga kesehatan yang datang ke klinik obgyn untuk melakukan pemeriksaan pap smear, mereka yakin dengan alat kesehatan yang akan dipakai pada saat pemeriksaan pap smear di klinik obgyn. Berbeda dengan informasi yang diterima dari Informan terkait dengan alat kesehatan yang akan digunakan pada saat pap smear, informan lain mengatakan bahwa ada rasa kekuatiran profesi bidan yang datang ke klinik obgyn untuk melakukan pemeriksaan pap smear dengan alat kesehatan yang ada di klinik tersebut. Demikian ungkapan dari masingmasing informan:
"Untuk alat kesehatan yang ada di klinik ini tetap kita gunakan untuk tindakan selalu yang steril, pasien yang berkunjung pasti akan aman bila dilakukan tindakan, tenaga bidan ingin melakukan tindakan apapun, contohnya penggunaan spekulum dari bahan steinles mereka bisa lihat sendiri bagaimana prosedur sterilkan alat".

(Informan 1)

"Tenaga kesehatan sendiri untuk memakai cocor bebek mereka tidak ada saya lihat adanya keraguan, mereka lebih yakin dengan kita karena langsung alat tersebut dibersihkan, spekulum vagina atau cocor bebek, arteri klem, oval klem, alat-alat itu saja steril semua, hanya saja menurut saya teman-teman bidan yang akan melakukan pap smear sebagian merasa sungkan. Ada yang sudah naik ke tempat tidur, pake alat itu perasaan gak nyaman, padahal hanya perasaan sendiri, kalau dianggap penggunaan alat sakit padahal tidak”.

(Informan 2)

"Di klinik obgyn, saya menggunakan alat kesehatan yang steril saat melakukan tindakan terhadap pasien yang berkunjung, saya rasa teman-teman bidan yang akan melaksanakan pap smear yakin mereka dengan kesterilan alat tersebut".

(Informan 3)

"Kalau pake spekulum hanya kuatir aja, alat yang terbuat dari steinles, merasakan sakit bila alatnya tidak disesuaikan dengan ukurannya, kalau kita yakin yang disposible sekali pake dibuang, maunya kayak prodia handscoonnya juga satu satu sekali pake buang”.

(Informan 4)

"Mengenai alat yang ada di klinik obgyn saya percaya kepada mereka untuk kesterilan alatnya, karena sama orang lain ajapun sama dengan perlakuan yang diberikan ke kita dalam penggunaan alat tetap proses steril”.

(Informan 5) 
"Saya pernah lihat mereka akan mensterilkan alatnya, dan saya yakit alat mereka emang steril dan untuk kekuatiran gak lah".

(Informan 6)

"Kalau alat kesehatan seperti cocor bebek, saya yakin kesterilannya terjamin, ukurannya ada yang besar dan ada yang kecil sesuai dengan ukuran pasien".

(Informan 7)

"Sewaktu pertama, saya pap smear di praktek dokter, jadi di sana menggunakan alat yang disposible jadi saya yakin steril, dan di rumah sakit kita juga saya yakin merena tetap mensterilkan alat”.

(Informan 8)

Rumah Sakit Tk II Putri Hijau sudah memiliki standart pensterilan alat kesehatan, hal ini diatur di dalam kebijakan komite PPI (Pencegahan dan Pengendalian Infeksi). Keberhasilan program pelayanan kesehatan tidak akan berjalan dengan baik dan lancar jika tidak didukung dengan adanya fasilitas yang menunjang seperti gedung, sarana/prasarana alat, dana, tenaga kesehatan pemberi pelayanan, serta birokrasi yang mengatur pelaksanaan program tersebut.

\section{Malas}

Di samping tugas dan tanggung jawab seorang bidan sehari-hari sebagai bidan pelaksana, mereka juga bertanggung jawab dalam hal administrasi pelayanan pasien, hal ini dibuktikan dari beban kerja yang tumpang tindih. Alasan malas yang diungkapkan oleh informan terkait juga dengan tidak adanya fasilitas jaminan kesehatan di tempat mereka bekerja saat ini sehingga mengharuskan mereka membayar tindakan pap smear dengan uang mereka sendiri dan jika mereka ingin melakukan pemeriksaan pap smear mereka malas pergi ke tempat lain yang memberikan pemeriksaan secara gratis karena alasan jarak yang jauh. Hal ini disampaikan oleh para informan yang diwawancarai, demikian hasil wawancara tersebut:
"Satu lagi malas aja kali ya, kadang kala bayarnya, di sinikan kalau gak di klaim BPJS ngak ada pemeriksaan, yang didukung BPJS seperti pirngadi, prodia hanya foto copi BPJS dan kita anjurkan ke sana, kalau di rumah sakit kita memang gak ada di dukung BPJS, malah kalau ada pasien minta pap smear bilang aja ngak bisa dikerjain di sini, tetapi ada juga satusatu kayak keluarga kawan-kawan mau juga".

(Informan 2)

"Malas, malas diperiksa karena buka buka, cuma itu tadi kalau mau melangkah berat, padahal kalau sudah diperiksa ya sudah, terserah gitu, ah malas".

(Informan 5)

"Malas aja, untuk melakukan pap smear gitu, apalagi harus bayar, kalau kita orang dalam kita cek ke luar bayar sendiri, kalau saya kemaren ke prodia gratis pap smear bawa kartu BPJS dan KTP".

\section{(Informan 6)}

"Malas, sibuk waktunya repot".

\section{(Informan 7)}

bahwa :

Menurut ungkapan informan lain

"Ya ... bisa dikatakan seperti itu, pernah kita tanya ke mereka (bidan) jawabannya malas aja untuk melakukan pap smear, kesibukan dan ada yang merasa malu sehingga membuat mereka mengurungkan niatnya, padahal tempatnya dekatnya ke klinik obgyn".

\section{(Informan 1)}

"Kalau saya pribadi karena seharian di klinik obgyn rasa malas itu tidak ada, banyak pasien yang dihadapi setiap harinya sesuai bermacam keluhan. Kalau sesama teman seprofesi ada yang mau untuk melakukan pap smear dan lebih banyak belum melakukan pemeriksaan pap smear, banyak hal yang membuat mereka malas ada rasa malu, dan karena bayar juga iya. Sehingga untuk melangkahkan kakinya terasa berat”.

(Informan 3) 
"Saya sering memberikan motivasi kepada pasien dan teman sekerja untuk mau melakukan pap smear, dan pada kenyataannya berbeda, saya sendiri belum melakukan secara rutin selama usia perkawinan sudah 30 tahun baru satu kali”.

\section{(Informan 4)}

"Saya selaku kepala ruang tetap sudah menjadi tanggung jawab menyampaikan informasi yang ada kepada teman-teman dan salah satunya untuk melakukan pap smear, saya memaklumi dengan kesibukan yang ada sehingga untuk melakukan hal tersebut terkadang tidak sempat, banyak yang harus dikerjakan seperti menolong partus, penulisan status rekam medik dan yang lain-lain”.

(Informan 8)

\section{Biaya}

Di Rumah Sakit Tk II Putri Hijau Medan untuk pemeriksaan pap smear belum bisa dilakukan secara gratis sehubungan dengan fasilitas kesehatan tidak melayani pemeriksaan sampel di laboratorium Rumah Sakit. Tetapi untuk pelayanan pemeriksaan pap smear bisa dilakukan di klinik obgyn. Sedangkan untuk pemeriksaan sampel di bawah mikroskop sesuai rujukan dokter obgyn ke laboratorium Prodia atau laboratorium klinik Thamrin. Demikian ungkapan dari beberapa informan, terkait dengan biaya :

"Kalau promosi pap smear sudah dilakukan ke batalyon dan ke kodim, dan saat kunjungan pasien di kliniki, brosur, dan leaflet. Jumlah kunjungan di klinik obgyn selalu banyak, tetapi untuk tenaga kesehatan sendiri sedikit. Untuk pemeriksaan sampel kita sudah mempunyai rujukan laboratorium Thamrin dan laboratorium Prodia dan untuk biaya pemeriksaan tergantung masing-masing laboratoriumnya ".

\section{(Informan 1)}

"Informasi tentang pap smear disampaikan kepada kawan dan bersama semua keluarga, ada gratis pemeriksaan pap smear dari prodia, kalau biaya sendiri sekitar Rp. 100.000 ke lab Thamrin, prosenya cepat biasanya 3 hari sudah selesai dititip sama anak saudara yang bekerja di RSU. Bunda Thamrin. Sosialisasi masa-masa dokter Santa diundang pembicara kepada ibu persit ke batalyon contohnya ke Paldam, untuk penyuluhan pap smear biasanya ibu-ibu pada sungkan kalau yang memberi materinya dokter laki-laki yang datang”.

\section{(Informan 2)}

"Informasi kalau ada pemeriksaan pap smear pasti kita sampaikan ke teman-teman dulu, seperti beberapa waktu yang lalu ada pemeriksaan gratis untuk pemeriksaan pap smear dari lab Prodia dan sudah kami sampaikan ke teman-teman dengan melengkapi foto copi BPJS, foto copi kartu kelurga dan foto copi KTP, pada saat pelaksanaannya bidan sendiri hanya 2 orang yang ikut untuk melakukan pap smear".

(Informan 3)

"Informasi tentang pap smear, harusnya orang lab yang menyampaikan hal tersebut bukannya dari ginok, karena lab prodia menghubungi lab sini, maunya waktu senam di hari jumat diumumkan, ini ngak hanya ngomong nanti hari Senin ada pap smear ya, mana sibuk kita ngurus berkas-berkas ini”.

\section{(Informan 4)}

"Promosi, biasanya dari Lab. Prodia gratis, bawa kartu BPJS, KK, KTP itu aja, biasanya orang poli memberi promosi ke pasien, ke kodim realisasinya kunjungan gak pernah tau, otomatis ke teman-teman, untuk keikutsertaan teman-teman, rata-rata semua ikut, cuman itu tadi tengang waktunya itu ngak sama, ada yang sedang haidlah".

(Informan 5)

"Setahu saya pemeriksaan pap smear bayarlah, karena periksanya ke luar tidak di klinik obgyn, untuk pengambilan sampelnya baru di klinik obgyn".

(Informan 6) 
"Biasanya pemeriksaan pap smear itu bayar, tergantung laboratorium mana yang kita tujuh dan atas petunjuk dokter obgyn, maunya rumah sakit kita kerjasama dengan laboratorium manapun walaupun bayar tapi ya dapatlah discountnya apalagi kita orang kesehatan ".

(Informan 7)

"Ya tetap, karena kita kasih promosi walaupun kita bukan sebagai pelaku tapi kita ngasih info yang benar gitu, kepasien ke teman-teman kita anjurkan. Rumah sakit belum pernah mendapat diskon, cuma rumah sakit pernah kerjasama dengan prodia tapi menggunakan BPJS kayaknya, mungkin karena itu ya kita pake BPJS kita ya disuruh menggunakan itu karena rumah sakit berusaha untuk itu. BPJS klaim di sini ngak bisa karena kita bukan PPK 1 kita $P P K$ 2, kalau kita ke luar bayar, biasanya mereka minta bayaran 40 sampai 50 ribu ya".

(Informan 8)

Dukungan dari instansi terkait diperoleh dengan diadakan pemeriksaan gratis pap smear pada acara tertentu seperti hari ulang tahun Kodam I/BB bekerjasama dengan BKKBN dan dinas kesehatan Provinsi Sumatera Utara, memperingati Hari Kesehatan Nasional dan lain sebagainya.

\section{PEMBAHASAN}

Dari hasil penelitian diperoleh 8 informan bahwa 1 orang dokter di klinik obgyn, 2 orang bidan di klinik obgyn, dan 5 orang bidan yang bekerja di ruang rawat inap kebidanan. Proses penelitian dalam pengumpulan data dilakukan dalam bentuk wawancara dengan menggunakan alat perekam. Pelaksanaan wawancara disesuaikan oleh aktivitas harian peneliti dan informan dengan tidak mengganggu kegiatan tugas pokok yaitu pelayanan di rumah sakit. Wawancara dilakukan oleh peneliti di ruang klinik obgyn, ruang rawat inap kebidanan dan di rumah salah satu informan yaitu informan 2. Dari pengumpulan data dan wawancara terhadap 8 informan, maka peneliti menemukan beberapa alasan mengapa profesi bidan tidak mau melakukan pemeriksaan pap smear di Rumah Sakit Tk II Putri Hijau Medan yaitu:

\section{Merasa Malu (Enggan)}

Dari beberapa informan yang dilakukan wawancara mengatakan rasa malu (enggan) terhadap dokter dan teman kerja saat dilakukan pap smear di ruang klinik obsgyn. Seharusnya sebagai tenaga kesehatan tidak ada sedikitpun perasaan malu baik terhadap dokter maupun teman kerja lainnya. Hal itu sudah biasa dilakukan oleh dokter maupun teman kerja di klinik obgyn, untuk melakukan pemeriksaan baik saat hamil maupun melahirkan. Terkadang persepsi seseorang yang salah sehingga merubah perilaku hidup sehat. Sering kita dengar perkataan "sehat itu mahal" atau "pencegahan lebih baik dari pada mengobati". Hal ini tidak merubah profesi bidan untuk melakukan pemeriksaan pap smear, walaupun dengan latar belakang pendidikan dan pengetahuan tentang kesehatan yang mereka miliki. Malu menurut Kamus Besar Bahasa Indonesia mengatakan bahwa merasa sangat tidak enak hati (hina, rendah dan sebagainya) karena berbuat sesuatu yang kurang baik (kurang benar benar, berbeda dengan kebiasaan, mempunyai cacat atau kekurangan dan sebagainya). Hal ini relevan dengan penelitian yang dilakukan Kesumawati, dkk (2016) tentang gambaran tentang Pengetahuan dan Deteksi Dini Kanker Serviks Kasus dan Kontrol di RSUD Sukoharjo terhadap penderita kanker serviks merasa malu dalam pemeriksaan pap smear sebanyak nihil $(0,0 \%)$ sedangkan bukan penderita kanker serviks sebanyak 7 orang $(22,2 \%)$.

\section{Rasa Takut}

Merupakan salah satu alasan beberapa informan untuk tidak melakukan pap smear, namun defenisi rasa takut setiap informan memiliki makna yang berbeda. Salah satu makna takut bagi informan adalah takut akan dijumpainya jenis penyakit dari hasil pemeriksaan pap smear, namun pada informan yang lain makna takut yang diungkapkan adalah takut akan alat yang akan digunakan pada proses pap smear. Walaupun beberapa informan telah mengetahui proses pemeriksaan pap smear, namun hal tersebut tidak 
mempengaruhi perubahan perilaku beberapa informan untuk melakukan pemeriksaan pap smear. pernyataan rasa takut tersebut yaitu takut ketahuan penyakitnya dan takut dengan alat kesehatan (cocor bebek) mengatakan sedikit sakit. Hal ini didukung oleh teori yang mengatakan bahwa pengetahuan baik tidak selalu diikuti oleh perilaku atau praktek yang baik, karena pengetahuan bukan merupakan faktor utama perubahan perilaku (Ernawati, 2014). Hal ini juga relevan dengan penelitian yang dilakukan oleh oleh Sinta (2015) dengan judul Hubungan Tingkat Pengetahuan Tentang Kanker Serviks Dengan Sikap Terhadap Pemeriksaan Pap Smear yaitu 3 dari ke 5 informan tersebut menyatakan mereka belum periksa karena berkaitan dengan waktu yang harus disediakan khusus untuk periksa, rasa malu saat pemeriksaan dan takut jika diketahui atau ditemukan penyakitnya. Sedangkan 2 dari ke 5 informan utama lainnya berkaitan rasa malu saat pemeriksaan dilakukan dan rasa takut jika ditemukan kanker serviks atau penyakit lainnya sehingga bisa membuat stres dan menambah pikiran.

\section{Merasa belum ada keluhan (Kelainan)}

Sebagai profesi bidan pengetahuan tentang kanker serviks pasti lebih baik daripada masyarakat umum, terkait dengan pengetahuan tentang tanda dan gejala serta pencegahannya. Namun pengetahuan yang ada tidak membuat informan berubah dan menganggap sepele terhadap pemeriksaan pap smear. Hal ini diungkapkan oleh beberapa informan pada saat wawancara. Pernyataan dari informan yang menyatakan bahwa tenaga kesehatan sendiri tidak memiliki motivasi untuk melakukan pemeriksaan pap smear, dikarenakan tidak ada kelainan. Dan ada juga informan percaya terhadap suaminya, yang beranggapan suamiselalu berada di samping. Hal ini relevan dengan sebuah penelitian di cina yang oleh Yao, etal. (2013) menyebutkan ada tujuh jawaban paling banyak yang dikemukakan oleh perempuan yang tidak ingin melakukan pap smear yaitu takut jika ternyata terdiagnosa penyakit, tidak ada keluhan atau ketidakyamanan, tidak mengetahui keuntungan dari deteksi dini kanker serviks, dan suami tidak mengizinkan melakukan deteksi dini kanker serviks.

\section{Kesterilan (Alat Kesehatan)}

Alat kesehatan di klinik obgyn diperoleh dari Rumah Sakit dan rekanan instansi pemerintah maupun swasta. Rumah Sakit Tk II Putri Hijau sudah memiliki standart pensterilan alat kesehatan, hal ini diatur di dalam kebijakan komite PPI (Pencegahan dan Pengendalian Infeksi). Informasi yang diperoleh dari informan mengatakan tentang alat kesehatan yang digunakan bahwa mereka yakin dengan alat kesehatan yang dipakai pada saat pemeriksaan pap smear di klinik obgyn. Dan ada informan lain mengatakan dalam penggunaan alat di klinik obgyn oleh petugas kesehatan, bahwa ditemukan adanya keluhan rasa sakit dan rasa kuatir yang dialaminya oleh bidan tersebut. Ada yang berkeyakinan menggunakan alat yang disposible seperti pengalaman dari salah satu informan di tempat praktek dokter lain. Sedangkan di klinik obgyn sebelum dan sesudah menggunakan alat kesehatan tetap dilakukan sesuai prosedur pensterilan. Berdasarkan penelitian Fransiska (2013) bahwa faktor-faktor yang menghambat responden melakukan Pap smear adalah faktor pengetahuan (63\%), faktor agama (46\%), faktor sosial budaya $(73 \%)$, faktor sumber informasi (77\%), faktor ekonomi (54\%), faktor motivasi dan dukungan dari suami dan keluarga (32\%), dan faktor fasilitas, pelayanan kesehatan (58\%). Jadi faktor fasilitas kesehatan dan pelayanan kesehatan yang ada di klinik obgyn bisa masalah jika hal ini tidak sesuai dengan prosedur proses dilakukan pemeriksaan pap smear.

\section{Malas}

Di samping tugas dan tanggung jawab seorang profesi bidan sehari-hari sebagai bidan pelaksana, mereka juga bertanggung jawab dalam hal administrasi pelayanan pasien, sehingga sangat melelahkan buat mereka. Dengan beban kerja yang tumpang tindih sehingga tidak ada waktu untuk melakukan pemeriksaan pap smear. Seperti inilah yang terjadi dari beberapa profesi bidan mengakibatkan muncul rasa malas tersebut. Alasan malas juga diungkapkan oleh informan 
lain terkait tidak ada jaminan kesehatan yang gratis dan harus membayar tindakan pap smear dengan uang mereka sendiri. Demikian ungkapan mereka; malas, sibuk waktunya repot, malas aja, untuk melakukan pap smear gitu, apalagi harus bayar, malas, malas diperiksa karena buka buka, cuma itu tadi kalau mau melangkah berat. Dari beberapa pernyataan ini, ternyata karena adanya pengutipan biaya administrasi tindakan pap smear membuat para informan malas untuk melakukan pemeriksaan. Dengan alasan yang sama, hal ini juga diungkapkan oleh Synta (2015) bahwa ada 3 dari ke 5 informan yang mengatakan malas melakukan pap smear karena biaya yang mahal.

6. Biaya

Untuk pemeriksaan pap smear di Rumah Sakit Tk II Putri Hijau Medan belum bisa dilaksanakan secara gratis, dikarenakan laboratorium tersebut tidak menyediakan layanan untuk pemeriksaan pap smear. Klinik obgyn hanya menyediakan tempat untuk pengambilan sampel saja, sedangkan untuk pemeriksaan sampel dilakukan sesuai rujukan dokter obgyn yaitu laboratorium Prodia dan laboratorium klinik Thamrin dengan biaya dibebankan kepada pasien. Pada momen tertentu laboratorium Prodia melaksanakan pemeriksaan pap smear diberikan secara gratis, seperti peringatan HKN dan peringatan Hari Kemerdekaan Indonesia dengan membawa persyaratan foto copi Kartu BPJS, foto copi kartu keluarga dan foto copi KTP. Namun profesi bidan belum menyadari pentingnya skrining kanker serviks dan keikusertaan dalam pemeriksaan pap smear. Walaupun promosi Srining kanker Serviks dengan pemeriksaan pap smear di Rumah Sakit Tk II Putri Hijau Medan belum terjadinya perubahan perilaku. Padahal promosi tentang skrining kanker serviks dengan pemeriksaan pap smear sudah disosialisasikan kepada ibu-ibu dari jajaran Kodam I/BB termasuk di dalamnya tenaga kesehatan (profesi bidan) dengan menghadirkan pembicara dari Dinas Kesehatan Provinsi dan pembicara dari Rumah Sakit Tk II Putri Hijau Medan. Seperti yang diungkapkan dari beberapa informan tentang biaya pemeriksaan pap smear oleh prodia dan lab
Thamrin, dengan perkiraan biaya sekitar Rp. 100.000. Sebelumnya pengambilan sampel di klinik obgyn kemudian dikirim bahan sampel laboratorium rujukan dari dokter obsgyn. Hal ini relevan dengan penelitian yang dilakukan Kesumawati, dkk (2016) tentang gambaran tentang Pengetahuan dan Deteksi Dini Kanker Serviks Kasus dan Kontrol di RSUD Sukoharjo diperoleh pasien yang tidak mempunyai biaya dengan kasus kanker serviks sebanyak 12 orang $(60 \%)$ sedangkan bukan penderita kanker serviks yang tidak punya biaya sebanyak 11 orang $(35,5 \%)$.

Beberapa alasan perilaku yang menjadi fenomena yang terjadi terhadap pemeriksaan pap smear profesi bidan terhadap di Rumah Sakit Tk II Putri Hijau Medan yaitu rasa malu (enggan), rasa takut, belum ada keluhan (kelainan), kesetrilan (alat kesehatan), malas dan biaya dan juga. Terlihat bahwa kekuatankekuatan penahan seperti alasan tersebut di atas lebih kuat dari kekuatan-kekuatan pendorong. Menurut Kurt Lewin (1970) berpendapat bahwa perilaku adalah suatu keadaan seimbang antara kekuatan-kekuatan pendorong (driving force) dan kekuatan-kekuatan penahan (restining forces). Perilaku itu dapat berubah apabila terjadi ketidakseimbangan antara kedua kekuatan tersebut di dalam diri seseorang sehingga ada tiga kemungkinan terjadinya perubahan perilaku pada diri seseorang yakni : a) Kekuatan-kekuatan pendorong meningkat: b) kekeuatan-kekuatan penahan menurun; c) kekuatan pendorong meningkat, kekuatan penahan menurun. Menurut Twoddle, apa yang sehat bagi seseorang bisa saja tidak sehat bagi orang lain. Ada dua hal yang timbul dari usaha untuk menjelaskan kesehatan dan atau penyakit, yaitu : a) karena terpaksa membicarakan kesehatan normal dengan kesehatan sempurna, kesehatan lebih dikenal sebagai norma sosial; b) defenisi kesehatan dilihat dari sudut sosial lebih khas daripada bila dilihat dari sudut biologis (Notoatmodjo, 2012).

\section{KESIMPULAN DAN SARAN \\ Kesimpulan}

Sumber informasi penelitian ini merupakan tenaga kesehatan yang berprofesi 
sebagai bidan sesuai dengan judul penelitian. Hasil penelitian ini menjawab tujuan umum dan tujuan khusus dari penelitian ini. Fenomena yang terjadi adalah profesi bidan tidak taat untuk melakukan pemeriksaan pap smear, walaupun mereka memiliki pengetahuan yang baik tentang kanker serviks dan proses pemeriksaan pap smear. Dari penelitian ini mengungkapkan bahwa ada beberapa alasan yang diungkapkan oleh profesi bidan terkait dengan pemeriksaan pap smear yaitu rasa malu untuk melakukan pemeriksaan, takut dengan proses pemeriksaan, belum ada keluhan atau kelainan yang dirasakan, kesterilan alat kesehatan yang akan digunakan, rasa malas dan mahalnya biaya pemeriksaan pap smear. Sebagai tenaga kesehatan seharusnya profesi bidan menjadi panutan atau role model terhadap masyarakat untuk melakukan pemeriksaan skrining kanker sedini mungkin namun dari hasil penelitian ini belum menunjukkan profesi bidan bisa menjadi panutan untuk masyarakat umum. Perilaku inilah yang harus dirubah oleh profesi bidan, dan mau memeriksakan dirinya sedini mungkin. Profesi bidan dapat berbagi pengalaman mereka dalam melakukan pemeriksaan skrining kanker kepada masyarakat umum sehingga akan memacu semangat masyarakat untuk melakukan pemeriksaan skrining kanker sedini mungkin. Hal ini akan mengurangi angka terjadinya kanker serviks jika didukung dengan ketaatan masyarakat melakukan pemeriksaaan pap smear.

\section{Saran}

1. Bagi masyarakat peneliti menyarankan pentingnya skrining kanker serviks dengan melakukan pemeriksaan pap smear untuk mendeteksi perubahan sel-sel pada serviks, dan tidak terjadi keterlambatan dalam memberikan pengobatan. Dengan pemeriksaan pap smear juga Sebagai langkah pertama para ibu yang sudah berkeluarga bisa menghentikan kemungkinan perkembangan kanker serviks, dengan cara menjalani pemeriksaan pap smear.
2. Untuk pihak Rumah Sakit Tk II Putri Hijau Medan, agar secara rutin dilakukan skrining kanker serviks dengan pemeriksaan pap smear secara gratis dengan fasilitas jaminan kesehatan yang ada.

3. Peneliti selanjutnya, agar termotivasi untuk melakukan penelitian berikutnya melihat apakah tenaga kesehatan khususnya bidan mau memeriksakan dirinya melakukan skrining kanker serviks dengan pemeriksaan pap smear.

\section{DAFTAR PUSTAKA}

Anita, T.S.P, 2016, Pengaruh Pemberian Booklet Kemoterapi Terhadap Kemampuan Perawatan Diri Penderita Kanker Payudara Pasca Kemoterapi Di Ruang Bedah Rumah Sakit Abdul Moeloek (Rsam) Bandar Lampung, Jurnal Kesehatan, Volume VII, Nomor 1, April 2016, hlm 26-33

August, dkk. 2016. Pemberdayaan Wanita dalam Bidang Kesehatan.Penerbit Andi, Yogyakarta

Azwar, C, Oruh, S, dan Harono, R. 2015, Studi Beban Kerja Bagi Perawat dan Bidan di Puskesmas Watampone dan Purkesmas Biru Kabupaten Bone, Media Kesehatan 2013-2016, vol Edisi 2, 2015, Makassar

Berita Satu. 2014, Hari Kanker Sedunia. Diakses tanggal 31 Maret 2017 Dari http://www.beritasatu.com/kesehatan/1645 92-di-indonesia-kasus-kanker payudaradan-serviks-tertinggi.html

Bustan, M.N. 2015. Manajemen Pengendalian Penyakit Tidak Menular, Penerbit PT. Rineka Cipta, Jakarta

Globocan 2012 (IARC), Cervical Cancer, Estimated Incidence, mortality and prevalence Worldwide in 2012. Section of Cancer surveillance. 2012. (Diakses tanggal 22 Mei 2017). Tersedia di: http://globocan.iarc.fr/old/FactSheets/canc ers/cervix-new.asp.

Gunawan, I. 2014. Metode Penelitian Kualitatif Teori \& Praktik, Penerbit PT Bumi Aksara, Jakarta 
Handayani, E.T, Ningtiyasari, N. 2014. Komitmen PUS entang Pelaksanaan Pap Smear Untuk encegah Kanker Serviks di Puskesmas Ngunut Kabupaten Tulungagung ahun 2014, Jurnal Universitas Tulungagung Bonorowo ol. 2 No.1 ahun 2014

Hartati, dkk. 2010. Cegah dan Deteksi Kanker Serviks, Penerbit PT. Elex Media Komputindo, Jakarta

Info BPJS Kesehatan. 2014. Integrasi Jamkesda Dalam Optimalisasi Program JKN diakses dari http://www.bpjskesehatan.go.id/bpjs/ dmdocuments/458a1cc2b107ca02247a545 89daaec4a.pdf pada tanggal 6 April 2017 Pukul 17.11 wib

Infodatin. 2015. Stop Kanker, situasi penyakit kanker dikutip dari http://www.depkes. go.id/resources/download/pusdatin/infodati n/infodatin-kanker.pdf pada tanggal 6 April 2017 pukul 8.59 wib

Kemenkes. 2014. Hilangkan Mitos entang Kanker. Diakses 31 Maret 2017, dari http://www.depkes.go.id

Kemenkes RI. 2014, Jkn Menjamin Pemeriksaan Deteksi Dini Kanker Leher Rahim Dan Payudara, diakses tanggal 31 Maret 2017 dari http://www.depkes.go.id

Kementerian Kesehatan RI Tahun 2015, Situasi Penyakit Kanker. Buletin Jendela Semester 1 Tahun 2015

Kompas. (2013), Jumlah Penderita Kanker Serviks Makin Tinggi. di akses tanggal 31 Maret 2017 dari http://nasional.kompas. com/read/2013/02/23/06321327/Jumlah.Pe nderita.Kanker.Serviks.Makin.Tinggi
Koran Sindo Daerah (2016), 110 Warga Medan Mengidap Kanker Serviks. Di akses dari http://koran-sindo.com/news.php?r $=5 \& n=122 \&$ date $=2016-103 ? \mathrm{r}=5 \& \mathrm{n}=$ 122\&date $=2016-11-03$ tgl 6 April 2017 pukul 20.44 wib

Kusumawardani, N, dkk. 2015, Penelitian Kualitatif di bidang kesehatan. Penerbit PT. Kanisius, Jakarta

Nugroho, T, Scorviani, V. 2012. Kamus Pintar Kesehatan. Penerbit Nuha Medika, Yogyakarta

Nugroho, T, dan Utama, B.I. 2014. Masalah Kesehatan Reproduksi Wanita.Penerbit Nuha Medika, Yogyakarta

Ompusunggu, F dan Bukit, E.K. 2013. Karakteristik, Hambatan Wanita Usia Subur Melakukan Pap Smear Di Puskesmas Kedai Durian.

Pratama, M.Y. 2017. Analisis Kualitas Kehidupan Kerja Perawat Pelaksana di Rumah Sakit Putri Hijau Medan. Jurnal Ilmiah Penelitian Kesehatan (Jumantik). http://www.jurnal.uinsu.ac.id/index.php/ke smas/article/view/1192, tanggal akses 1 Juni 2018.

Sulistiowati, E, Sirait, A..M. 2014. Pengetahuan Tentang Faktor Risiko, Perilaku Dan Deteksi Dini Kanker Serviks Dengan Inspeksi Visual Asam Asetat (Iva) Pada Wanita Di Kecamatan Bogor Tengah, Kota Bogor, Bul. Penelit. Kesehat, Vol. 42, No. 3, September 2014: 193-202

Triwibowo, C dan Pusphandani, M.E. 2015, Pengantar Dasar Ilmu Kesehatan Masyarakat, Penerbit Nuha Medika, Yogyakarta

Tanto, C dan Liwang, L, Hanifati, S, Pradipta, E.A. 2014. Kapita Selekta Kedokteran Edisi IV Jilid I, Penerbit Media Aesculapius, Jakarta.

Wawan, A dan Dewi. 2016. Teori \& Pengukuran Pengetahuan, Sikap, dan Perilaku manusia. Penerbit Nuha Medica, Yogyakarta 